\title{
Investasi Edukasi Literasi Keuangan untuk Anak Usia Dini di Indonesia
}

\author{
Anisa Yunita Sari ${ }^{1 凶}$, Naili Sa ${ }^{\circledR}$ da $^{2}$ \\ Pendidikan Anak Usia Dini, Universitas Narotama, Indonesia(1), Pendidikan Anak Usia Dini, \\ Universitas Muhammadiyah Surabaya, Indonesia(2) \\ DOI: $10.31004 /$ obsesi.v6i3.1369
}

\begin{abstract}
Abstrak
Nilai-nilai karakter yang dapat ditanamkan pada literasi keuangan adalah keterampilan mengalokasikan keuangan, melatih kontrol emosi serta kemampuan membedakan antara keinginan dan kebutuhan. Penelitian ini bertujuan untuk mengetahui gambaran strategi investasi edukasi literasi keuangan untuk anak usai dini di Indonesia. Penelitin ini menggunakan metode literatur review dengan menggunakan berbagai sumber yang relevan dari: 6 buku,12 artikel jurnal, 1 laporan kebijakan, dan 3 website resmi. Sumber literatur yang digunakan pada rentan tahun 2013-2021. Hasil penelitian dapat disimpulkan bahwa strategi edukasi literasi keuangan di Indonesia dilakukan oleh pemerintah dan pihak swasta. Pelaksanaan dari strategi edukasi literasi keuangan memenuhi dua poin yaitu: 1)tersedianya media edukasi literasi keuangan untuk anak usia dini 2) sosialisasi pelatihan tentang literasi keuangan pada guru PAUD yang dilakukan oleh pihak swasta dengan program CSR (Corporate Social Responbility). Program sosialisasi edukasi literasi keuangan untuk guru pada jenjang PAUD belum dilakukan oleh pihak pemerintah.
\end{abstract}

Kata Kunci: : paud; literasi keuangan; program; strategi nasional

\begin{abstract}
Skills to distribute funds, emotional control, and the ability to discern between desires and requirements are all character qualities that may be fostered in financial literacy..Financial literacy is an essential program to be taught in early childhood. Learning financial literacy in children from an early childhood is able to develop attitude skills and knowledge about basic financial literacy aspects that are useful for children's daily lives. This study aims to determine the strategic picture of investing in financial literacy education for early childhood in Indonesia. This study uses the literature review method by using various relevant sources from: 6 books, 12 article journals, 1 policy report, and 5 official websites. Literature sources used in vulnerable 2016-2021.According to the study's findings, Indonesia's financial literacy education policy is implemented by both the government and the private sector. The adoption of a financial literacy curriculum plan accomplishes two goals:1) the availability of early childhood financial literacy educational media that can be accessed 2) The private sector's CSR initiative has helped to socialize financial literacy instruction for early childhood teachers. The government has not implemented a financial literacy education socialization policy for teachers at the early childhood education level.
\end{abstract}

Keywords: early childhood education; financial literacy; programme; national strategy.

Copyright (c) 2022 Anisa Yunita Sari, Naili Sa`ida

$\triangle$ Corresponding author :

Email Address : anisa.yunita@narotama.ac.id (Surabaya, Indonesia)

Received 21 May 2021, Accepted 8 July 2021, Published 26 Desember 2021 


\section{PENDAHULUAN}

Investasi edukasi tentang literasi keuangan merupakan program yang esensial untuk diajarkan pada anak usia dini. Rumusan ataupun batasan pengertian literasi keuangan pada anak usia dini mengacu pada standar perkembangan anak yang telah disepakati dan digunkana pada kurikulum 2013 PAUD dan standart nasional PAUD. Literasi keuangan penting untuk anak usa dini karena perkembangan anak pada tahapan berikutnya ditentukan dengan kualitas pendidikan awal sebagai fondasi dalam menyiapkan generasi penerus (Muh. Hasbi, Herlianthy, et al., 2020)

Tingkat kesejahteraan masyarakat memiliki korelasi dengan literasi keuangan (Brilianti \& Kautsar, 2020; Gathergood, 2012), penelitian tersebut menyimpulkan bahwa pemahaman masyarakat yang kurang terhadap literasi keuangan akan berpengaruh terhadap kemampuan mengontrol diri yang lemah serta berdampak pada tingkat hutang yang berlebih. Peran pendidikan adalah sebagai pijakan untuk menghadapi tantangan perkembangan dunia yang cepat dan dinamis.

Berdasarkan five pillars education (UNESCO, 2014) fokus dari peran pendidikan adalah learning to transform oneself and society yaitu pendidikan harus bisa menjembatani apa yang sedang menjadi permasalahan nyata untuk memberikan perubahan yang bermakna bagi kehidupan untuk diri sendiri maupun untuk masyarakat. Anak-anak akan dihadapkan pada tentangan perkembangan dunia yang cepat,dinamis dan tidak dapat diprediksi maka pendidikan harus dapat memberikan penguatan tentang pemahaman literasi keuangan sebagai salah satu keterampilan dasar kehidupan. Esensi dari pendidikan diharapkan adanya perubahan yang relatif permanen dari praktik yang diperkuat dalam behavioral potentiality (Matthew, 2008). Pendidikan bukan hanya transfer pengetahuan saja, tetapi menanamkan nilai karakter, untuk membentuk kebiasaan serta dilakukan secara konsisten dan sedini mungkin.

Investasi literasi keuangan pada anak usia dini dapat diartikan sebagai upaya terencana untuk mengembangkan keterampilan sikap dan pengetahuan tentang aspek-aspek literasi keuangan dasar dan akan mendapatkan manfaatnya dikemudian hari. Peranan strategi literasi keuangan yang selama ini dilakukan di Indonesia meliputi beberapa sektor terutama di bidang pendidikan. Berdasarkan hasil penelitian (Wahyuni \& Reswita, 2020) pemahaman tentang literasi keuangan untuk anak usia dini masih perlu adanya peningkatan karena kurangnya muatan kurikulum tentang sosial finansial pada anak usia dini serta guru masih memiliki tingkat kemampuan yang rendah terhadap pendidikan sosial finansial. Pengajaran pada anak usia dini yang masih dalam tahapan pra operasional konkrit tentu memiliki karakteristik dan tingkat kesulitan yang berbeda, terutama dalam mengkreasikan pengajaran yang kontekstual, seperti halnya kejadian-kejadian yang sering dialami anak, namun belum terkemas pada pendidikan literasi keuangan

Tantangan dalam mengimplementasikan literasi keuangan untuk anak usia dini pada lingkup kelas adalah: 1)adanya rencana pembelajaran yang disusun oleh pendidik, namun tanpa objek yang jelas terkait tujuan pembelajaran dan bagaimana menjalankan program pembelajaran yang akan dilakukan, 2) Pendidik mengerti tujuan pembelajaran serta pentingnya pendidikan literasi keuangan untuk anak usia dini namun masih kesulitan dalam mengkreasikan dan menggunakan metode yang tepat dalam memberikan pembelajaran yang bermakna dan mudah dipahami oleh anak. Tantangan pada pengajaran literasi keuangan pada anak usia dini lebih ditekankan pada kemampuan pendidik dalam aspek pedagogi untuk memberikan pengajaran yang bermakna dan mudah dipahami oleh anak. Tugas pendidik adalah menyampaikan pemahaman teknis tentang literasi keuangan menjadi sesuatu yang sederhana, mudah dipahami dan menyenangkan untuk anak usia dini tanpa menghilangkan esensi dari literasi keuangan tersebut.

Pada penelitian ini akan menggali tentang investasi literasi keuangan yang dilakukan di Indonesia, terkait dengan kebijakan, sarana dan prasarana serta pengembangan SDM tenaga pendidik. Pendidik merupakan kunci dalam penyampaian materi pengajaran di kelas 
yang selanjutanya akan dapat diimplementasikan anak pada kehidupan sehari-hari. Hal tersebut memungkinkan anak akan lebih bijak dan terampil dalam penerapan literasi keuangan.

\section{METODOLOGI}

Metode yang digunakan dalam menulis artikel ini adalah literature review. Metode literature review (Cooper, 1988) dilakukan dengan empat tahapan yaitu:1) problem formulation, 2) data collection, 3) data evaluation, 4) analysis and intepration, 5) public presentation diilustrasikan pada gambar 1 .

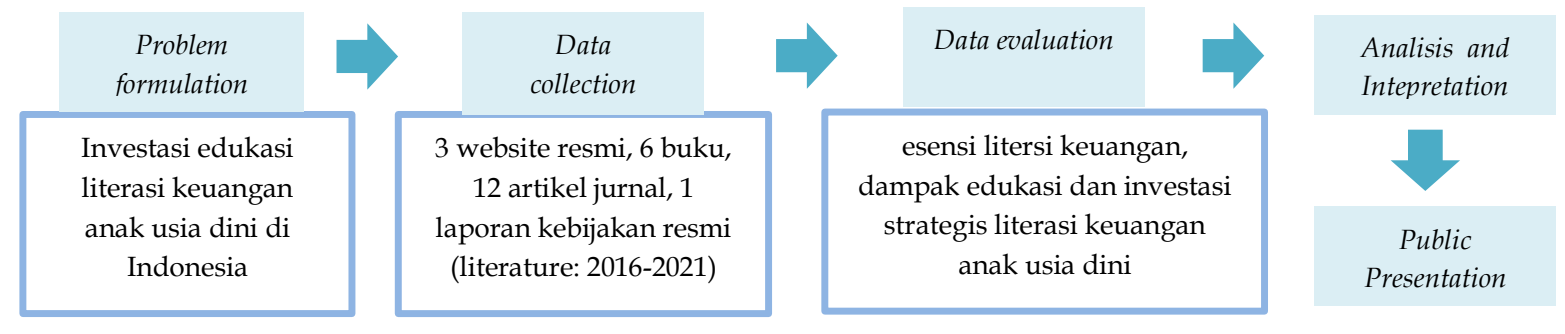

\section{Gambar 1. Tahap Penelitian}

Tujuan dari literature review adalah untuk mendapatkan pemahaman pada kajian topik tentang literasi finansial pada anak usia dini dan menyajinya dalam bentuk laporan tertulis. Analisis yang dilakukan pada penelitian ini adalah peneliti mengaitkan antara kejadian yang sedang diteliti dengan sumber data. Data yang diperoleh akan memberikan gambaran dan memberikan solusi terkait investasi edukasi literasi keungan anak usia dini yang telah diterapkan di Indonesia.

\section{HASIL DAN PEMBAHASAN}

Berdasarkan hasil tinjauan literatur,maka dapat menjawab pertanyaan mengenai strategi literasi keuangan pada anak usia dini di Indonesia, Berdasarkan sumber literatur yang diperoleh selanjutnya dievaluasi dan dianalisis. Pembahasan tentang investasi literasi keuangan anak usia dini yang diidentifikasikan sesuai kriteria yaitu; esensi literasi keuangan untuk anak usia dini, dampak edukasi literasi keuangan terhadap kesejahteraan ekonomi dan peran strategi investasi pendidikan literasi keuangan untuk anak usia dini di Indonesia. Selengkapnya lihat tabel 1.

\section{Pembahasan}

Esensi literasi keuangan untuk anak usia dini adalah kecakapan untuk mengimplementasikan pemahaman serta keterampilan untuk mengelolah keuangan agar dapat membuat keputusan yang efektif sebagai keterampilan kecakapan hidup (Fabris \& Luburic, 2016; Suhardi et al., 2017). Pendidikan keuangan memberikan pengetahuan keterampilan dan percaya diri (Fabris \& Luburic, 2016) diantaranya adalah: 1) knowledge :pemahaman tentang literasi keuangan ,2) skills:terampil mengelolah keuangan ,3) confidence :percaya diri membuat keputusan tentang keuangan. Nilai-nilai karakter yang ditanamkan dalam literasi keuangan adalah budaya gemar menabung, melatih kontrol emosi (tidak impulsif) dalam membelanjakan, membedakan antara keinginan dan kebutuhan serta dapat mengalokasikan keuangan untuk menabung dan berbagi.

Pendidikan literasi keuangan tidak hanya tentang menabung dan berhemat pada saat penggunaan uang. Berhemat mengandung arti, menggunakan sumber daya yang tersedia sebagai bentuk rasa syukur dan dapat membedakan mana kebutuhan dan mana keinginan. Menabung mengandung arti kemampuan anak untuk menunda keinginan (delay gratification) (Hasbi, Herlianthy, et al., 2020). Pemahaman literasi keuangan tidak hanya memberikan 
pemahaman anak tentang uang teatapi juga membentuk karakter. Pendidikan karakter perlu adanya konsistensi, usaha yang terus menerus dan lingkungan yang kondusif untuk membentuk kebiasaan menjadi sikap dan menetap menjadi karakter seseorang.

Tabel 1: Identifikasi Permasalahan

\begin{tabular}{|c|c|c|}
\hline \multirow[t]{2}{*}{ No } & \multicolumn{2}{|c|}{$\begin{array}{c}\text { Referensi } \\
\end{array}$} \\
\hline & $\begin{array}{ll}\text { Esensi Literasi Keuangan Untuk }\end{array}$ & Anak Usia Dini \\
\hline 1. & Financial Education Of Children And Youth & (Fabris \& Luburic, 2016) \\
\hline 2. & Materi Pendukung Literasi Finansial & $\begin{array}{l}\text { (Suhardi, Muhammad, Iskandar, et al., } \\
\text { 2017) }\end{array}$ \\
\hline 3. & $\begin{array}{l}\text { New Vision for Education: Fostering Social and Emotional } \\
\text { Learning through Technology }\end{array}$ & $(\mathrm{WEF}, 2016)$ \\
\hline 4. & $\begin{array}{l}\text { Pengintegrasian Pendidikan Sosial dan Finansial dalam } \\
\text { Kurikulum Tingkat Satuan Pendidikan (KTSP) dan } \\
\text { Pengembangan RPP di Satuan PAUD }\end{array}$ & (Muh. Hasbi, Herlianthy, et al., 2020) \\
\hline & \multicolumn{2}{|c|}{ Dampak Edukasi Literasi Keuangan Terhadap Kesejahteraan Ekonomi } \\
\hline 5. & $\begin{array}{l}\text { Apakah Literasi Keuangan Memengaruhi } \\
\text { Kesejahteraan Rumah Tangga di Indonesia? }\end{array}$ & (Brilianti \& Kautsar, 2020) \\
\hline 6. & $\begin{array}{l}\text { Self-Control, Financial Literacy and Consumer Over- } \\
\text { Indebtedness }\end{array}$ & (Gathergood, 2012) \\
\hline 7. & Five Pillars Education & (UNESCO, 2014) \\
\hline 8. & $\begin{array}{l}\text { New Vision for Education : Fostering Social and Emotional } \\
\text { Learning through Technology }\end{array}$ & $(\mathrm{WEF}, 2016)$ \\
\hline 9. & $\begin{array}{l}\text { Strategi Nasional Literasi Keuangan Indonesia (Revisit } \\
\text { 2017) }\end{array}$ & $(\mathrm{OJK}, 2017)$ \\
\hline 10. & $\begin{array}{l}\text { Siaran Pers Awal Tahun Satgas Waspada Investasi } \\
\text { Minta Masyarakat Waspadai Fintech dan Infestasi } \\
\text { Ilegal }\end{array}$ & (OJK, 2021) \\
\hline 11. & $\begin{array}{l}\text { Satgas Waspada Investasi: Kerugian Akibat Investasi } \\
\text { Ilegal Rp114,9 }\end{array}$ & (Tirto, 2021) \\
\hline & Peran Strategi Investasi Pendidikan Literasi Keuanga & n Untuk Anak Usia Dini di Indonesia \\
\hline 12. & $\begin{array}{l}\text { The Economics Of Inequality: The Value Of Early Childhood } \\
\text { Education }\end{array}$ & (Heckman, 2012) \\
\hline 13. & $\begin{array}{l}\text { Pendidikan Anak Usia Dini Konseptualisasi Peran } \\
\text { Strategis dalam Pendidikan Literasi Keuangan Anak } \\
\text { melalui Pendekatan Systematic Review }\end{array}$ & (Yuwono, 2021) \\
\hline 14. & The Economic Returns to Early Childhood Education. & (Karoly, 2016) \\
\hline 15. & $\begin{array}{l}\text { Recomendarions for Improfing Youth Financial Literacy } \\
\text { Education }\end{array}$ & (Heuberger et al., 2018) \\
\hline 16. & Early Childhood Development Economic Development & (Rolnick \& Grunewald, 2003) \\
\hline 17. & $\begin{array}{l}\text { Penerapan Penilaian Capaian Perkembangan Anak } \\
\text { dalam Pendidikan Sosial dan Finansial di Satuan PAUD }\end{array}$ & $\begin{array}{l}\text { (Muhammad Hasbi, Wardhani, et al., } \\
\text { 2020) }\end{array}$ \\
\hline 18 & Pedoman Pendidikan Sosial Finansial di Satuan PAUD & (Muhmmad Hasbi et al., 2013) \\
\hline 19 & $\begin{array}{l}\text { OJK Luncurkan Buku untuk Tingkatkan Literasi } \\
\text { Keuangan Anak-anak - Finansial Bisnis.com }\end{array}$ & $(\mathrm{OJK}, 2020 \mathrm{~b})$ \\
\hline 20 & Sikapiuangmu (mini youtube series OJK) & (sikapiuangmu, 2020) \\
\hline 21 & $\begin{array}{l}\text { Metode/Kegiatan, Media, dan Sumber Belajar dalam } \\
\text { Pelaksanaan Pendidikan Sosial dan Finansial di Satuan } \\
\text { PAUD }\end{array}$ & (Muh. Hasbi, Faridah, et al., 2020) \\
\hline 22 & $\begin{array}{l}\text { Konsep Pendidikan Sosial Finansial Serta Peran } \\
\text { Pendidik dan Tenaga Kependidikan (PTK), Orang Tua, } \\
\text { Mitra, dan Komunitas }\end{array}$ & (Muh. Hasbi, Paramita, et al., 2020) \\
\hline 23 & $\begin{array}{l}\text { AXA Mandiri dan AXA Implementasikan Perempuan } \\
\text { Cerdas Perempuan Mandiri }\end{array}$ & (AXA mandiri, 2016) \\
\hline 24 & $\begin{array}{l}\text { Corporate Social Responbility di PT. Prudential Life } \\
\text { Assurance }\end{array}$ & (Fairuz et al., 2019) \\
\hline
\end{tabular}


Pemahaman literasi keuangan perlu dilakukan sedini mungkin, karena tingkat kesejahteraan masyarakat memiliki korelasi dengan literasi keuangan (Brilianti \& Kautsar, 2020; Gathergood, 2012), penelitian tersebut menyimpulkan bahwa pemahaman masyarakat yang kurang terhadap literasi keuangan akan berpengaruh terhadap kemampuan mengontrol diri yang lemah serta berdampak pada tingkat hutang yang berlebih. Berdasarkan five pillars education (UNESCO, 2014) fokus dari peran pendidikan adalah learning to transform oneself and society yaitu pendidikan harus bisa menjembatani apa yang sedang menjadi permasalahan nyata untuk memberikan perubahan yang bermakna bagi kehidupan untuk diri sendiri maupun untuk masyarakat.

Tujuan dari pendidikan adalah menjadikan arah dari pembangunan berkelanjutan dalam era Sustainable Development Goals (SDGs) berdasarkan keputusan dari forum PBB yang telah disepakati pada tanggal 2 agustus 2015. Parameter peradaban yang lebih baik yaitu dengan mengacu capaian dari 17 poin SDGs, salah satunya adalah terwujudnya pertumbuhan ekonomi yang stabil, tentu hal ini tidak terlepas dengan pendidikan literasi keuangan (Fabris \& Luburic, 2016). 21 st Century Skills (WEF, 2016) menyatakan bahwa literasi keuangan merupakan salah satu dari literasi dasar yang harus dimiliki pada abad ke-21.

Masyarakat yang memiliki pemahaman literasi keuangan yang baik, akan berpengaruh terhadap inklusi keuangan dan dapat mewujudkan masyarakat yang sejahtera (OJK, 2017). Data statistik yang dilakukan oleh (OJK, 2021) menunjukkan bahwa tingkat pemahaman masyarakat tentang literasi keuangan masih perlu ditingkatkan. Selama 10 tahun terakhir tercatat kerugian investasi illegal mencapai $\mathrm{Rp} 144,9$ triliun (Tirto, 2021). Angka tersebut dapat diminimalisir dan dialih fungsikan sebagai dana investasi untuk pengembangan sumber daya manusia yang berkualitas. Praktek investasi illegal dan fintech peer to peer akan terus berkembang jika permintaan dan minat masyarakat tinggi. Untuk mencegah hal tersebut maka perlu adanya perbaikan kulitas SDM (sumber daya manusia) tentang literasi keuangan.

Salah satu sektor yang dapat digunakan sebagai pengembangan SDM adalah melalui pendidikan. Pendidikan pada anak usia dini merupakan investasi paling efektif dan efisien untuk pengembangan ekonomi, semakin awal investasi maka semakin besar keuntungan yang didapatkan (Heckman, 2012). Konseptualisasi peran strategi literasi keuangan yang diterapkan pada anak usia dini meliputi 3 peran yaitu: 1) peran pemerintah dalam perancangan kurikulum literasi keuangan, 2) peran guru dan orangtua dalam penerapkan pendidikan literasi keuangan, 3) peran ketersediaan media pembelajaran baik online maupun offline (Yuwono, 2021)

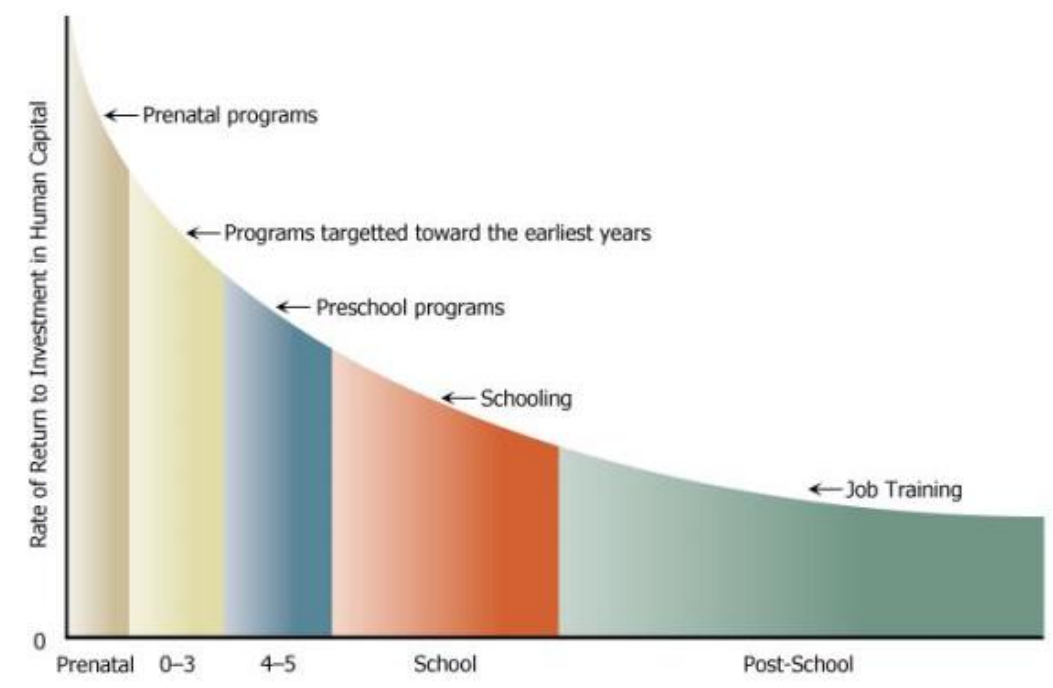

Gambar 2. Return to a dollar Invested (Heckman, 2012) 
Dalam grafik returns to a dollar invested, memberikan informasi bahwa investasi pendidikan yang dilakuakn pada anak usia dini memiliki keuntungan lebih tinggi. Selaras dengan penelitian (Karoly, 2016) yang dilakukan dengan mengkomparasikan analisis manfaat biaya untuk program sekolah di AS menyatakan bahwa investasi pendidikan anak usia dini dapat menghemat anggaran dan menghasilkn keuntungan yang lebih banyak daripada investasi pendidikan yang dilakukan pada jenjang lebih lanjut.

Dalam kehidupan sosial anak akan selalu bersinggungan terhadap transaksi penggunaan uang. Memahami dan mengelolah keuangan sudah menjadi bagian dari kecakapan hidup dan perlu ditanamkan sejak dini, maka anak akan diajarkan untuk mengambil sikap yang benar. Berdasarkan hasil penelitian, anak yang memiliki kontrol terhadapa keuangan, tercatat lebih baik dalam mengimplementasikan keuangan pada usia 32 tahun seperti memiliki rumah, dana investasi dan dana pensiun (Heuberger et al., 2018). Sejalan dengan pendapat diatas (Rolnick \& Grunewald, 2003) menyatakan bahwa kualitas hidup seorang anak dan kontribusinya terhadap masyarakat dapat ditelusuri kembali terhadap kualitas kehidupannya saat lahir hingga usia 5 tahun.

Manfaat pendidikan literasi keuangan untuk anak usia dini tidak hanya terbukti dapat menghemat anggaran secara ekonomis, namun ada beberapa manfaat yang tidak dapat dikalkulasikan dengan nominal seperti nilai-nilai karakter: berperilaku baik, percaya diri, konsisten dan berani mengambil keputusan. Nilai-nilai karakter yang baik merupakan bekal kecakapan hidup yang harus dimiliki oleh anak. Pendidikan mengemas keterampilan kognitif dengan keterampilan yang mengandung nilai-nilai karakter, sehingga perlu adanya upaya yang terus menerus dan berkalanjutan.

Penerapan pembelajaran literasi keuangaan pada anak usia dini, pendidik harus memahami terkait ruang lingkup tentang literasi keuangan dan sesuai dengan perkembangan anak serta terintegrasi pada kegiatan pembelajaran. Jika pendidik tidak memiliki pemahaman terkait literasi keuangan untuk anak usia dini maka akan menemukan kesulitan dalam pengukuran keberhasilan dalam pembelajaran. Penilaian pendidikan literasi keuangan pada anak usia dini meliputi unsur sebagai berikut: autentik, sistematis, objektif akuntabel, berkesinambungan, mendidik,menyeluruh dan bermakna (Hasbi, Paramita, et al., 2020)

Strategi adalah suatu rencana yang disusun secara cermat untuk mencapai tujuan sasaran khusus (KBBI, 2001). Upaya kerjasama untuk meningkatkan literasi keuangan untuk anak usia dini tidak hanya dilakukan oleh pihak pemerintah tetapi juga dilakukan oleh pihak swasta sebagai partner strategis. Hal tersebut sesuai dengan program yang diusung oleh presiden Joko Widodo jika pembangunan sumber daya manusia akan menjadi prioritas utama.

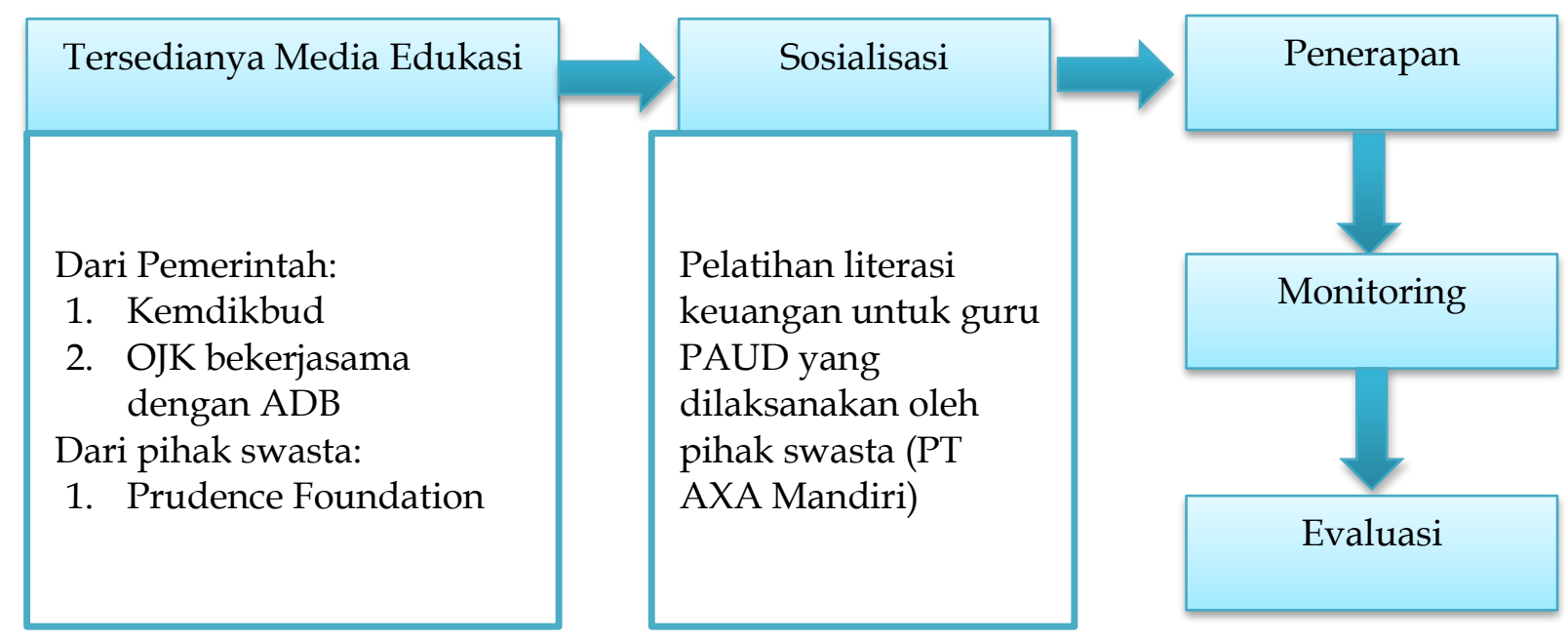


Strategi edukasi literasi keuangan di Indonesai yang dilakukan pemerintahan yaitu oleh kementerian pendidikan dan kebudayaan dengan menerbitkan buku GLN (Gerakan Literasi Nasional). Buku GLN membahas tentang literasi finansial di sekolah, keluarga dan masyarakat (Suhardi et al., 2017). Buku tersebut dapat diunduh secara gratis pada website resmi kemdikbud di https://gln.kemdikbud.go.id/. Buku pedoman pendidikan sosial finansial di satuan PAUD juga diterbitkan oleh kemdikbud sebagai pedoman pengajaran yang dikhususkan untuk para guru. Pembahasan pada buku pedoman pendidikan sosial finansial di satuan PAUD, berisi tentang bagaimana esensi pendidikan literasi keuangan anak usia dini, implementasi kegiatan dan evaluasi pembelajaran (Muhmmad Hasbi et al., 2013). Kemdikbud juga memiliki website resmi bernama "ruang guru PAUD" atau sering disingkat dengan sebutan "anggun paud", yang terdapat pada laman https://anggunpaud.kemdikbud.go.id berisi tentang informasi pendidikan anak usia dini yang dapat diakses oleh guru, praktisi maupun orangtua. Website anggun paud berisi 30 buku elektronik sebagai sumber belaja untuk orangtua dan menerbitkan 4 modul tentang penerapan sosial finansial yang ditujukan untuk pendidik dan juga orangtua (Kemdikbud, 2020).

Upaya pemerintah dalam edukasi literasi keuangan juga dilakukan oleh OJK (otoritas jasa keuangan) sebagai lembaga independen yang dibentuk berdasarkan UU nomor 21 tahun 2011 yang melakukan pengawasan dan pengaturan pada seluruh kegiatan pada sektor jasa keuangan. Pada pengembangan infrastruktur edukasi literasi keuangan (OJK, 2020a) mengadakan pelaksanaan webinar Training of Trainer (ToT) yang diikuti pada guru jenjang SMA sederajat, karena pada jenjang SMA terdapat mata pelajaran ekonomi, sedangkan literasi finansial pada guru jenjang pendidikan anak usia dini belum dilakukan.

OJK bekerjasama dengan ADB (Asia Development Bank) menerbitkan buku literasi keuangan untuk anak usia dini pada tanggal 8 oktober 2020 (OJK, 2020b). OJK menerbitkan 4 seri buku cerita bergambar untuk anak yang mengusung tema: mengenalkan konsep, kegunaan uang (kebutuhan dan keinginan) serta dapat menumbuhkan budaya menabung dan konsep berbagi, dan menerbitkan satu buku pendamping yan berjudul menumbuhkan "Kecakapan Literasi Keuangan Untuk Anak Usia Dini" yang ditujukan kepada orangtua dan guru(OJK, 2020a) . OJK melakukan pengembangan terhadap minisite Aplikasi Online Platform Informasi dan Edukasi Keuangan (OPIK) "sikapiuangmu" dalam rangka peningkatan program literasi keuangan.

Semua buku yang bertajuk literasi keuangan anak usia dini yang diterbitkan OJK dapat diunduh secara gratis pada website https://sikapiuangmu.ojk.go.id. Pada bulan oktober 2020, "sikapiuangmu" merilis 3 seri video bertajuk literasi keuangan untuk anak yang dapat diakses pada kanal youtube "sikapiuangmu OJK" (sikapiuangmu, 2020). Penayangan pada seri video tersebut paling tinggi dilihat sebanyak 1,2 ribu kali penayangan, dan yang paling sedikit 40 kali penayangan (data diambil pada tanggal 6 maret 2021) .

Selain penggunaan media pembelajaran yang dapat diakses secara online, metode yang dapat digunkan untuk mengenalkan literasi keuangan untuk anak usia dini adalah: diskusi, bermain peran, kegiatan seni, kunjungan lapangan, proyek dan bercerita selain itu juga dapat diberikan pengutan pada keteladanan dan pembiasaan (Muh. Hasbi, Faridah, et al., 2020). Implementasi metode pembelajaran literasi keuangan untuk anak usia dini dibutuhkan kecakapan pedagogi pendidik agar pembelajaran yang diterapkan sesuai dengan tahap perkembangan anak, menyenangkan, bermakna dan tanpa menghilangkan esendi dari pendidikan literasi keuangan tersebut.

Upaya dalam meningkatkan pendidikan literasi keuangan pada anak usia dini, tidak hanya dilakukan oleh pihak negeri/pemerintah tetapi pihak swasta juga berperan untuk meningktkan literasi keuangan anak usia dini dengan program CSR (Corporate Social Responbility) untuk menciptakan SDM unggul. Kolaborasi yang efektif dan optimal dapat menumbuhkan pemahaman literasi keuangan anak usia dini sebagai bagian dari pembentukan profil pelajar pancasila sejak usia dini ( Hasbi, Nugraha, et al., 2020). 
Meski program yang dilakukan oleh pihak swasta tidak terlepas dengan program marketing yang dilakukan namun ada beberapa keuntungan melalui program CSR yang dapat membantu pemerintah untuk meningkatkan SDM terutama untuk bidang pendidikan literasi keuangan. Beberapa pihak swasta yang melakukan CSR terkait pendidikan literasi keuangan untuk anak usia dini adalah Prudence Foundation dan PT.Axa Mandiri. Salah satu program literasi keuangan yang dikembangkan oleh Prudential adalah Cha-ching money smart kids dengan mengusung konsep pembelajaran keuangan dasar: memperoleh, menyimpan, mebelanjakan dan donasi (Fairuz et al., 2019). Program cha-ching juga meuncul pada cartoon webtoon dengan menampilan video literasi keuangan pada platform digital youtube channel "chaching video" yang tersedia dalam beberapa bahasa, temasuk dalam bahasa Indonesia. Selain itu juga memiliki platform instagram chachingid dan website www.chaching.cartoonnetworkasia.com yang berisi tentang edukasi keuangan untuk anak usia dini yang dapat dimanfaatkan secara gratis oleh orangtua, pendidik dan anak usia dini.

Berbeda dengan program yang dilakukan oleh Prudence Foundation dengan fokus literasi keuangan untuk sekmen anak-anak, PT. Axa Mandiri fokus pada pengembangan tenaga pendidik. PT.Axa Mandiri mengadakan pelatihan literasi keuangan untuk guru PAUD terkait dengan pelatihan metode belajar kreatif literasi keuangan untuk anak. Program tersebut bernama "Perempuan Cerdas Perempuan Mandiri" yang dilaksanakan di 11 kota di jawa tengah dan jawa barat dan mencapai jumlah 5.196 guru PAUD (Axa Mandiri, 2016).

Strategi literasi keuangan pendidikan anak usia dini di Indonesia masih memenuhi dari 2 poin utama yaitu: adanya media edukasi dan sosialisasi. Program sosialisasi hanya dilakukan oleh pihak swasta (PT.Axa Mandiri) dan berpusat hanya pada 11 kota besar di Jakarta, Jawa Barat, Jawa Tengah dan Jawa Timur. Sosialisasi terkait literasi keuangan yang dilakukan oleh pihak pemerintah hanya dilakukan pada guru-guru jenjang SMA sementara untuk sosialisai pada guru paud belum dilakukan. Jika sosialisasi yang dilakukan belum maksimal, maka masyarakat juga kurang mengenal tersedianya produk media edukasi tentang literasi keuangan yang dapat dipelajari dan diakses.

\section{SIMPULAN}

Edukasi literasi keuangan untuk anak usia dini di Indonesia dilakukan oleh pihak pemerintah dan juga pihak swasta, serta memenuhi dua poin yaitu: 1) tersedianya layanan media edukasi, 2) adanya sosialisasi. Namun belum dilakukan monitoring dan evaluasi terkait penerapan edukasi literasi keuangan pada pendidikan anak usia dini, apakah sudah sesuai harapan. Saran yang dapat dilakukan terhadap investasi literasi keuangan untuk anak usia dini di Indonesia adalah: 1) Menciptakan ekosistem sekolah yang literate finansial seperti menyelenggarakan open house sebagai sekolah percontohan ataupun wadah kegiatan belajar para praktisi pendidikan dan terdapat mentoring sebagai bahan evaluasi, 2) Kerjasama dengan pihak-pihak yang ikut berperan dalam pengembangan SDM. Keuntungan yang diperoleh pihak swasta adalah adanya pemotongan pajak jika berperan dalam pengembangan SDM. Hal tersebut tertuang pada UUD no 45 tahun 2019 tentang penghitungan penghasilan kena pajak dan pelunasan pajak penghasilan dalam tahun berjalan. Sedangkan keuntungan dari pihak pemerintah bekerjasama dengan pihak swasta adalah mendapatkan partner strategis.

\section{UCAPAN TERIMA KASIH}

Tim Penulis mengucapkan terimakasih kepada penulis artikel jurnal, buku ataupun ebook serta media pendukung lain yang relevan: website resmi, youtube dan sumber media informasi. Keberadaan sumber informasi tersebut sangat bermanfaat sebagai data analisis dalam penelitian literature review tentang "Investasi Edukasi Literasi Keuangan Untuk Anak Usia Dini di Indonesia" 


\section{DAFTAR PUSTAKA}

AXA mandiri. (2016). AXA Mandiri dan AXA Implementasikan Perempuan Cerdas Perempuan Mandiri. Axa Mandiri. https://axa.co.id/axa-mandiri-dan-axaimplementasikan-perempuan-cerdas-perempuan-mandiri-tingkatkan-kompetensitenaga-pendidik-paud/

Brilianti, F., \& Kautsar, A. (2020). Apakah Literasi Keuangan Memengaruhi Kesejahteraan Rumah Tangga di Indonesia. Kajian Ekonomi \& Keuangan, 4(2), 104-115. https://doi.org/10.31685/kek.v4i2.541

Cooper, H. M. (1988). The integrative research review: a systematic aproach.

Fabris, N., \& Luburic, R. (2016). Financial education of children and youth. Journal of Central Banking Theory and Practice, 5(2), 65-79. https:// doi.org/10.1515/jcbtp-2016-0011

Fairuz, R. A., Faachira, F., Raharjo, S. T., \& Resnawaty, R. (2019). Corporate Social Responbility di PT. Prudential Life Assurance. Prosiding Penelitian Dan Pengabdian Kepada Masyarakat, 5(3), 251. https://doi.org/10.24198/jppm.v5i3.20087

Gathergood, J. (2012). Self-Control, Financial Literacy and Consumer Over-Indebtedness. SSRN Electronic Journal. https:// doi.org/10.2139/ssrn.2005031

Hasbi, Muh., Faridah, I., Paramita, D., Herlianthy, S. L., \& Ervinna Kristyaningsih, M. (2020). Metode/Kegiatan, Media, dan Sumber Belajar dalam Pelaksanaan Pendidikan Sosial dan Finansial di Satuan PAUD. Kementerian Pendidikan dan Kebudayaan.

Hasbi, Muh., Herlianthy, S. L., Paramita, D., Kristyaningsih, E., \& Wahyuni, M. (2020). Pengintegrasian Pendidikan Sosial dan Finansial dalam KTSP dan Pengembangan Perencanaan Pembelajaran di Satuan PAUD (Vol. 2, Issue 1). Kementerian Pendidikan dan Kebudayaan.

Hasbi, Muh., Nugraha, A., Herlianthy, S. L., Faridah, I., Paramita, D., \& Kristyaningsih, E. (2020). Konsep Pendidikan Sosial Finansial Serta Peran Pendidik dan Tenaga Kependidikan (PTK), Orang Tua, Mitra, dan Komunitas. Kementerian Pendidikan dan Kebudayaan.

Hasbi, Muh., Paramita, D., Herlianthy, S. L., Faridah, I., Kristyaningsih, E., \& Rosita, W. (2020). Penerapan Penilaian Capaian Perkembangan Anak dalam Pendidikan Sosial dan Finansial di Satuan PAUD. Kementerian Pendidikan dan Kebudayaan.

Hasbi, Muhammad, Wardhani, L. K., \& Widyawati, E. (2020). Penilaian Perkembangan Anak Selama Belajar dari Rumah. 1-27.

Hasbi, Muhmmad, Siantajani, Y., Wardhani, B., Kristyaningsih, E., Prawoto, A., \& Rachmadani, R. (2013). Pedoman Pendidikan Sosial Finansial di Satuan PAUD. Kemeneterian Pendidikan dan Kebudayaan.

Heckman, J. J. (2012). The Heckman Equation. Make greater investments in young children to see greater returns in education, health and productivity. The Heckman Equation, 1-2.

Heuberger, B., Kasman, M., \& Hammond, R. A. (2018). Recomendarions for Improfing Youth Financial Literacy Education. The Brokings Institution. https://www.brookings.edu

Karoly, L. A. (2016). The Economic Returns to Early Childhood Education. Future of Children, 26(2), 37-55. https://doi.org/10.1353/foc.2016.0011

KBBI. (2001). Arti kata strategi - Kamus Besar Bahasa Indonesia (KBBI) Online. https://kbbi.web.id/strategi

Kemdikbud. (2020). Anggun PAUD - Ruang Guru dalam Jaringan. https://anggunpaud.kemdikbud.go.id/berita/index/20201006112337/30-SumberBelajar-Orang-Tua

Matthew, H. (2008). Theori'es of Learning (Teori Belajar). Edisi Ketujuh. Jakarta: Prenada Media Group.

OJK. (2017). Strategi Nasional Literasi Keuangan Indonesia (Revisit 2017). Otoritas Jasa Keuangan Republik Indonesia.

OJK. (2020a). Laporan Triwulan II-2020 OJK. Otoritas Jasa Keuangan Republik Indonesia. www.ojk.go.id 
OJK. (2020b). OJK Luncurkan Buku untuk Tingkatkan Literasi Keuangan Anak-anak Finansial Bisnis.com. https://finansial.bisnis.com/read/20201007/90/1302214/ojkluncurkan-buku-untuk-tingkatkan-literasi-keuangan-anak-anak

OJK. (2021). Siaran Pers Awal Tahun Satgas Waspada Investasi Minta Masyarakat Waspadai Fintech dan Infestasi Ilegal.

Rolnick, A. J., \& Grunewald, R. (2003). Early childhood development = economic development. Fedgazette, December, 6-12.

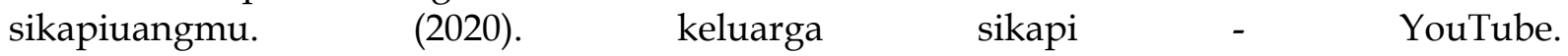
https://www.youtube.com/results?search_query=keluarga+sikapi

Suhardi, D., Muhammad, H., Iskandar, H., Surapranata, S., Farid, H., Daryanto, \& Suprayitmo, T. (2017). Materi Pendukung Literasi Finansial. In Gerakan Literasi Nasional. http://gln.kemdikbud.go.id/glnsite/buku-literasi-finansial/

Tirto. (2021). Satgas Waspada Investasi: Kerugian Akibat Investasi Ilegal Rp114,9 - Tirto.ID. https:// tirto.id/ satgas-waspada-investasi-kerugian-akibat-investasi-ilegal-rp1149gaFP

UNESCO. (2014). Education for Sustainable Development 2005-2014 Five pillars of ESD Learning to know Knowledge, values and.

Wahyuni, S., \& Reswita, R. (2020). Pemahaman Guru mengenai Pendidikan Sosial Finansial pada Anak Usia Dini menggunakan Media Loose Parts. Obsesi : Jurnal Pendidikan Anak Usia Dini, 4(2), 962. https:// doi.org/10.31004/obsesi.v4i2.493

WEF. (2016). New Vision for Education : Fostering Social and Emotional Learning through Technology. World Economic Forum, March, 36. http://www3.weforum.org/docs/WEF_New_Vision_for_Education.pdf

Yuwono, W. (2021). Pendidikan Anak Usia Dini Konseptualisasi Peran Strategis dalam Pendidikan Literasi Keuangan Anak melalui Pendekatan Systematic Review. Obsesi : Jurnal Pendidikan Anak Usia Dini, 5(2), 1419-1429. https://doi.org/10.31004/obsesi.v5i2.663 